\title{
Diversity of cattle raising systems and its effects over forest regrowth in a core region of cattle production in the Brazilian Amazon
}

\author{
Raquel Carvalho ${ }^{1} \cdot$ Ana Paula Dutra de Aguiar ${ }^{2}$. Silvana Amaral ${ }^{3}$
}

Received: 30 August 2019 / Accepted: 29 February 2020 / Published online: 26 March 2020

(C) The Author(s) 2020

\begin{abstract}
Roughly $60 \%$ of all deforested lands in the Brazilian Amazon are covered with pastures, putting cattle raising in evidence as a major driver of deforestation and also of forests' regrowth. Still, the role of cattle raising diversity in the landscape dynamics of this region remains poorly understood. To contribute to this discussion, we combined data from semi-structured interviews and quantitative spatially explicit methods to characterize and spatialize cattle raising systems and explore the effects of this diversity over secondary vegetation between 2004 and 2014 in Pará, a hotspot of deforestation and core region of cattle production. We quantified the use of different pasture management strategies to classify small- and large-scale operations into systems with high or low impact against pastures' degradation. High-impact systems were mapped in regions with consolidated infrastructure and high accumulated deforestation, where they expanded. On the contrary, low-impact systems were more widespread and found near forest frontiers, shrinking over time. High-impact systems had less secondary vegetation, while under low-impact systems, as a result of strategies with little or no effect against degradation, the historical pattern of concentration of this cover prevailed. Better infrastructure and access to markets as well as higher accumulated deforestation are underlying conditions related to the emergence of intensification and, as it is still unclear whether intensification is indeed capable of sparing land, the expansion of intensive cattle raising systems has the potential to configure landscapes with reduced forested areas, either primary or secondary.
\end{abstract}

Keywords Cattle raising systems $\cdot$ Pasture management $\cdot$ Forest regrowth $\cdot$ Intensification $\cdot$ Brazilian Amazon

Communicated by Luis Lassaletta

Electronic supplementary material The online version of this article (https://doi.org/10.1007/s10113-020-01626-5) contains supplementary material, which is available to authorized users.

Ana Paula Dutra de Aguiar

anapaula.aguiar@su.se

Raquel Carvalho

raca.raquel.carvalho@gmail.com

Silvana Amaral

silvana.amaral@inpe.br

1 Pós-Graduação Centro de Ciência do Sistema Terrestre, Instituto Nacional de Pesquisas Espaciais, Avenida dos Astronautas, 1.758. Sala $1,1^{\circ}$ andar. Jardim da Granja, São José dos Campos, SP 12227-010, Brazil

2 Stockholm Resilience Centre, Stockholm University, Kräftriket 2B, SE-10691 Stockholm, Sweden

3 Divisão de Processamento de Imagens (DPI), Instituto Nacional de Pesquisas Espaciais, Avenida dos Astronautas, 1.758, Jardim da Granja, São José dos Campos, SP 12227-010, Brazil

\section{Introduction}

Roughly $60 \%$ of deforested lands in the Brazilian Amazon are covered with pastures, making of cattle raising the main deforestation driver, and the most pervasive land-use in the biome, where one-third of national herds are concentrated (Arima et al. 2005; Bowman et al. 2012; Lapola et al. 2014; IBGE 2016). Predominantly extensive, cattle raising is often defined as little productive, with less than $40 \%$ of grazing areas supporting stocking rates higher than 0.5 animal unity per hectare, and only $3 \%$ of herds being finished under intensive and highly productive systems (Cezar et al. 2005; Escada et al. 2005; Merry and Soares-Filho 2017). The historical expansion of cattle raising in the Brazilian Amazon has therefore followed a pattern of deforestation, implementation of pastures with little or no technical concerns, early degradation, abandonment, and forest regeneration, as expansion proceeds over newly deforested lands (Costa 2004, 2009; Escada et al. 2005; Dias-Filho 2011, 2015). Following a peak of deforestation in 2004 though, command and control operations, restrictions to credit, and purchasing of cattle conditioned to the 
registration of properties in the Rural Registering System (CAR) led deforestation rates to their lowest level since 1988 (Alix-Garcia et al. 2018; Arima et al. 2014; Lapola et al. 2014). The G4 cattle agreement conceived in 2009 was crucial in this regard as it forced major slaughterhouses and retailers to commit to zero deforestation (Gibbs et al. 2016; Lambin et al. 2018). Despite pressure to halt deforestation in the beef production chain, pastures, herds, slaughtering, and exports steadily expanded, suggesting that more intensive strategies to manage pastures were being adopted instead of an uncontrolled expansion over newly deforested lands (Pacheco and Poccard-Chapuis 2012; COMEX-STAT/MDIC 2016; IBGE 2016). As a positive outcome of increased pressure over beef production and in alignment with the landsparing approach, intensification emerged as an important strategy to produce forest conservation and reduce carbon emissions (Cohn et al. 2011; Garrett et al. 2018). However, disconnected from other conservation and law enforcement measures, it is not clear whether cattle raising intensification could produce conservation results or, on the contrary, aggravate social-environmental impacts as intensified systems expand yet requiring large amounts of land and natural resources, agricultural inputs and government subsidies (Merry and Soares 2017; Garrett et al. 2018; Kaimovitz and Angelsen 2008).

Besides a major driver of deforestation, cattle raising also plays an important role in the dynamics of secondary vegetation, through the process of pasture degradation (Uhl et al. 1988; Nepstad et al. 1996; Costa 2004, 2009; Mesquita et al. $2001,2015)$. Estimated to affect $50 \%$ of pastures in the biome, the agricultural degradation of pastures (hereafter referred simply as pasture degradation) is a reversible process, through which deforested lands converted into pastures are progressively colonized by new assemblages of secondary species (weeds to bushes) that, competing with planted grasses, reduce forage and animal productivity, making cattle production unviable (Arima et al. 2005; Dias-Filho 2011, 2015). As degraded pastures are abandoned, forests regenerate and secondary vegetation accumulates: between 2004 and 2014, for instance, $33.4 \%$ (or 57.9 thousand $\mathrm{km}^{2}$ ) of the total amount of secondary vegetation was mapped in areas of pastures (Terraclass 2014). Notwithstanding the pervasiveness of cattle raising, the widespread degradation of pastures and the relevance of secondary vegetation for global issues such as climate change (Neef et al. 2005; Orihuela-Belmonte et al. 2013; Aguiar et al. 2016), biodiversity conservation (Benayas et al. 2009), and food security (Pereira and Vieira 2001; Strassburg et al. 2014), it remains poorly understood how different cattle raising systems relate with forest regrowth.

Despite various studies referring to the diversity of cattle raising operations in the Amazon biome, to the best of our knowledge, there is not a comprehensive characterization of systems, as only specific aspects of cattle raising operations, especially the size of properties, are used in these classifications. Walker et al. (2000), for instance, refer to small producers (landholdings < 100 ha) and "fazendeiros" (landholdings $>1000 \mathrm{ha}$ ), mentioning differences in wealth and cultural backgrounds as relevant in land management although further details in this regard are not provided. Cézar et al. (2005) use feeding plans as a criterion to classify systems as extensive (pastures only), semi-intensive (pastures and supplementation without confinement), and intensive (pasture, supplementation, and confinement), indicating how they might be spatially distributed in Brazil. Using the stages of the beef cycle, Bowman et al. (2012) state that systems found in the Amazon range from traditionally extensive full-cycle to cow-calve operations or fattening operations, either in small or large scales without mentioning whether they differ in terms of land management. Almeida et al. (2016a, 2019) apply a decision tree to remote sensing data to classify and spatialize agricultural systems in Rondonia including integrated croplivestock among them without providing details concerning land management.

In this work, as a first attempt to understand the role of different cattle raising systems in the dynamics of secondary vegetation, we combine data from semi-structured interviews and spatially explicit methods to classify and spatialize systems. Building on this diversity, we explore the effects of different levels of intensity of pasture management over secondary vegetation in Pará, a historical hotspot of deforestation, and a core region of cattle production in Brazil (Prodes 2019; IBGE 2016). Semi-structured interviews were performed in multiple sites with heterogeneous characteristics and these data used to characterize systems considering various attributes regarding the scale of operations and strategies of pasture management. These attributes were then applied to a spatial database to spatialize systems, analyze changes in their distribution, and explore their effects over the spatialtemporal clustering patterns of secondary vegetation in 2004 and 2014.

\section{Methods}

\section{Study area and fieldwork sites}

With 1.24 million $\mathrm{km}^{2}$, Pará (Fig. 1) hosts a great diversity of landscapes that include consolidated areas of mechanized agriculture and cattle raising (e.g. Southeast) and forest frontiers, where cattle raising is still the major driver of deforestation (e.g. Southwest). To cover this diversity of systems, we selected nine study sites for fieldwork based on: 


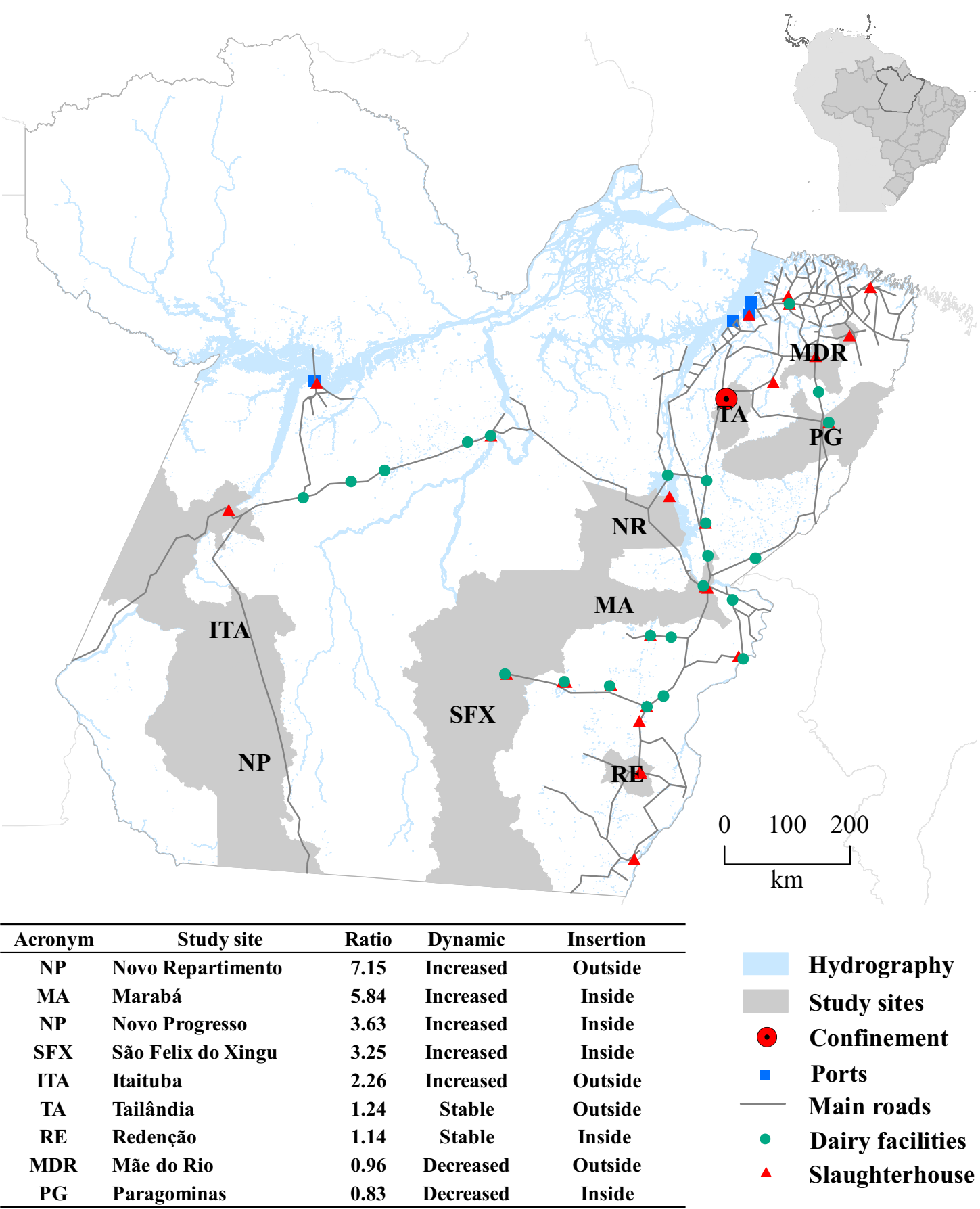

Fig. 1 Study sites and the criteria used to select sites. Ratio calculated dividing the number of heads of cattle in 2015 by the number of heads of cattle in 2000. Dynamics indicates in which sites herds increased (ratio $>$ $1.5)$, decreased $($ ratio $<1)$, or were stable $(1<$ ratio $<1.5)$. Insertion

(i) A ratio calculated by the number of heads of cattle in 2015 divided by the number of heads of cattle in 2000 , which gives a quantitative dimension of the evolution of herds in the period, i.e., ratios $>1.5$, herds increased; ratio $<1$, herds decreased; and ratios $>1$ and $<1.5$, herds stabilized. Data to calculate ratios were obtained from the indicates how different study sites are connected with Federal Sanitary Inspection System (SIF) slaughterhouses based on the traceability data for 2013

Monthly Cattle Inventory data from the National Institute of Geography and Statistics (IBGE 2016).

(ii) Insertion in the network of industrial slaughterhouses, i.e., inside-sites supplying at least one industrial slaughterhouse registered in the Federal Sanitary Inspection System (SIF) and outside- 
sites not meeting this criterion. Insertion was defined using the traceability database of purchasing operations of the three major industrial slaughterhouses operating in the biome in 2013.

\section{Strategies of pasture management}

To identify and characterize systems and strategies of pasture management, we adopted the snowballing method (Kelley et al. 2003, Bernard 2006) to perform 94 semi-structured interviews with 42 technicians and 52 cattle breeders (small and large). Technicians from ADEPARÁ (Pará Agricultural Defense Agency) were the first informants to be interviewed, for being more accessible and better equipped to provide contacts and facilitate access to small and large cattle breeders. Fieldwork was performed from August through December 2016 with 4 to 8 days being spent in each study site, and on average, four informants being interviewed per day. Using an open questionnaire (Online Resource 1), the semi-structured interviews aimed at identifying systems that informants had direct experience, with or knowledge of, in their specific regions. Besides identifying systems, informants were requested to characterize these systems with as many details as possible. All interviews were transcribed and these data compiled and tabulated in a sheet using a list of attributes (Online Resource 1), comprising 110 data entries. Based on these data, systems were characterized in terms of the percentage of adoption of different strategies calculated as the number of affirmative responses divided by the total number of responses (affirmative and negative) concerning a given strategy. To standardize and inform sample sizes, we calculated for each percentage of adoption the respective response rate (RR), using the total number of responses (affirmative and negative) divided by the total number of records informing about a given system (Baruch 1999; Kelley et al. 2003).

\section{Diversity of cattle raising systems and spatial-temporal analysis of secondary vegetation}

Aiming at assessing the diversity of cattle raising systems and exploring its effects over the dynamics of secondary vegetation we proceeded as follows:

(i) We built a spatial database covering the period between 2000 and 2014 organizing data as attributes in $10 \mathrm{~km} \times 10 \mathrm{~km}$ cells defined in agreement with the extent of the study area (Online Resource 2). Attribute values for the cellular space were calculated using attribute tables of layers with support of the Fill Cell Plugin (TerraME) (Aguiar et al. 2012), an add-on plugin that allows information coming from different geometries (vector, raster, or cellular) to be homogenized and aggregated in a single spatial-temporal layer, providing a database for modeling and statistical analysis. Calculation of values for the cellular space followed recommendations provided by the FillCell Plugin tutorial that indicates which operators should be used in agreement with the type of data that is being aggregated to the database.

(ii) We excluded all cells under protected areas, except Environmental Protected Areas (APAs) which in agreement with the Brazilian framework can be used for productive purposes pending the definition of rules in their respective management plans. As none of the APAs in our study region has management plans, we assume they do not impede the development of cattle raising. The cells coinciding with the Metropolitan Region of Belém, Marajó Island, and Lower Amazon river were also excluded as cattle raising operations there differ from those developed in the lowlands of Pará.

(iii) We defined the attributes and respective threshold values applied in the spatialization of systems based on data from semi-structured interviews as follows. The attributes and respective threshold values are presented in Online Resource 3.

Size of properties. As reported in fieldwork, properties in small-scale systems are smaller than 501 ha; therefore, to spatialize these systems, the attribute applied was "class of properties $<501$ ha" and the threshold value set as above the mean value. By the same token, properties in large-scale systems are larger than 1000 ha; thus, to spatialize these systems, we applied "class of properties $>1001$ hectares" as an attribute and set the threshold value as above the mean value.

Stocking rates. Threshold values for this attribute were the minimum and maximum values of stocking rates reported for each system in interviewees.

Pasture management. Based on an extensive review of the literature, the practices and techniques of pasture management reported in semi-structured interviews were separated as having a high or low impact in precluding pasture degradation (Online Resource 4). Assuming that high-impact strategies implied intensification of pasture management and that low-impact strategies had limited or no impact in this regard, we used the area covered by clean and dirty pastures as proxies of pasture management strategies. For the systems where, based on the percentages of use of pasture management strategies, highimpact strategies (i.e., chemical fertilization, liming, division-rotation of pastures, mechanical weeding, and semi-confinement) prevailed, the threshold value for clean pasture was set above the mean, and for dirty pasture as below the mean. In systems where low-impact 
strategies (i.e., manual weed control, herbicides, and fire) prevailed, the threshold value was set as above the mean for dirty pasture, and below the mean for dirty pasture. Additional attributes. In the spatialization of the system characterized by strong connections with major slaughterhouses, we used the weighted distance to the nearest slaughtering facility measured by a Generalized Proximity Matrix (GPM) (Aguiar et al. 2012) and exports of live animals, beef, and leather as additional attributes. In the spatialization of the system characterized by dairy production, we used the size of dairy herds as an additional attribute that included.

Spatial-temporal dynamics of systems. To analyze how the spatial distribution of systems changed over time, the same attributes and threshold values above described were applied to data between 2000 and 2004 to spatialize systems. For the attribute of stocking rates, we used data available in Pacheco and Poccard-Chapuis (2012).

(iv) To explore the spatial-temporal dynamics of secondary vegetation between 2004 and 2014 in different systems, we analyzed the quantitative evolution and percentages of the area of secondary vegetation per deforested land and the area under clusters of cold spots (low values) and hotspots (high values) of secondary vegetation per deforested (Carvalho et al. 2019).

\section{Results}

\section{Systems and pasture management strategies}

Small-scale cattle raising operations in Pará are developed through the mixed dairy-beef and subsistence systems (Online Resource 4) both predominantly associated with properties with less than 500 ha, although holdings in the mixed dairy-beef system can be as large as 645.8 ha. Herds range from 6 to 10 cattle heads, but herds as large as 550 heads were reported in the mixed dairy-beef system as well. Stocking rates range from 0.2 and 2 animal units/ha in the subsistence system, with rates as high as 3.5 animal units/ha being reported in the mixed system (minimum 0.1 animal units/ha). The mixed system is usually found associated with diversified agriculture of fruit and annual crops. In the subsistence system though, pastures are commonly expanded to the limit of properties thus restricting any other productive activities. Either when the main objective of operations is dairy production, as in the mixed system, or when weaned male calves are the main focus, like in the subsistence system, the cow-calve predominates as the beef cycle stage $(87.1 \%$ and $100 \%$, respectively). The primary connections of small-scale systems with the market are the middlemen (mixed, $75 \%$; subsistence, $80 \%$ ) who purchase cattle on behalf of large ranchers.

Large-scale operations connect with the professional and the traditional systems (Online Resource 4) developed in properties larger than 1000 ha; however, properties in these systems may less than 500 ha in the Northeast and larger than 10,000 ha in the southeast. The size of herds in large-scale systems ranges from 700 to 5000 heads, with smaller properties hosting from 250 to 700 heads. Stocking rates range from 1 to 2.8 animal units/ha in the professional, and from 1.39 to 2 animal units/ha in the traditional. Operations in the professional system privilege the full cycle in different properties $(69.2 \%)$, followed by fattening $(23.1 \%)$. The full cycle in different properties $(47.2 \%)$ and finishing $(31.4 \%)$ also prevail in the traditional system but the cow-calve stage $(11.4 \%)$ as well appears as relevant in Novo Progresso, especially because weaned calves, traded in Mato Grosso, are subject of reduced tax pays. Even though cattle raising is the main focus, we found properties in the traditional system where degraded pastures are being substituted by palm oil in the Northeast (Tailândia and Mãe do Rio) and açaí in the Southeast (São Felix do Xingu). The major slaughterhouses (66.7\%) are the professional system's main connection with the market, followed by live cattle trading $(21.2 \%)$. For the traditional system though, the market is predominantly accessed through the middlemen $(31 \%)$, followed by trades of live cattle $(27.6 \%)$, and with major $(20.7 \%)$ and local slaughterhouses (17.2\%) (a complete list of attributes characterizing different systems is available in Online Resource 5).

Table 1 shows how high- and low-impact strategies of pasture management are used in different systems. From the eight different strategies identified Pará, we identified chemical fertilization and liming preceded or not by soil analysis, division and rotation of pastures, mechanical control of weeds, and semi-confinement (fattening only) as strategies of high impact against degradation, and manual control of weeds, the use of herbicides, and fire as strategies of low impact. (Online Resource 6 brings a complete analysis of the expected effects of these strategies in precluding pasture degradation according to previous research.)

As seen in Table 1, the percentages of adoption of lowimpact strategies are similar between small-scale systems. However, when high-impact strategies are considered, the percentages are always higher for the mixed system in comparison with the subsistence for which some high-impact strategies; i.e., chemical fertilization and liming are not even reported. For high-impact strategies reported for both systems, percentages are always higher in the mixed system, except for mechanical weeding for which values are similar (mixed, $47.1 \%$ versus $36.4 \%$ ). Concerning large-scale systems, the strategies with high impact prevail in the professional system instead of the traditional, except again for mechanical weeding (professional, 100\%; traditional, 95.2\%). Differences are 
Table 1 Prevailing management strategies with high or low impact in precluding pasture degradation in different cattle raising systems. (\%) Percentage of adoption of a pasture management strategy calculated as the total number of affirmative responses divided by the total number of affirmative and negative responses. (RR) Response rates, the total number sponses divided by the total number of responses informing about a given system of affirmative and negative re-

\begin{tabular}{|c|c|c|c|c|c|}
\hline \multirow[t]{2}{*}{ Impact } & \multirow[t]{2}{*}{ Strategy } & \multicolumn{2}{|c|}{ Large-scale systems } & \multicolumn{2}{|l|}{ Small-scale systems } \\
\hline & & $\begin{array}{l}\text { Professional } \\
(\%)\end{array}$ & $\begin{array}{l}\text { Traditional } \\
(\%)\end{array}$ & $\begin{array}{l}\text { Mixed dairy-beef } \\
(\%)\end{array}$ & $\begin{array}{l}\text { Subsistence } \\
(\%)\end{array}$ \\
\hline \multirow[t]{10}{*}{ High } & Chemical fertilization & 100 & 54.2 & 45 & Not used \\
\hline & $\mathrm{RR}(\%)$ & 71.42 & 68.57 & 68.9 & 68.42 \\
\hline & Liming & 100 & 57.9 & 29.4 & Not used \\
\hline & $\mathrm{RR}(\%)$ & 67.85 & 54.28 & 58.6 & 68.42 \\
\hline & Division-Rotation & 100 & 53.8 & 61.1 & 16.7 \\
\hline & RR (\%) & 57.1 & 74.3 & 62 & 63.2 \\
\hline & $\begin{array}{l}\text { Mechanical weed } \\
\text { control }\end{array}$ & 100 & 95.2 & 47.1 & 36.4 \\
\hline & $\mathrm{RR}(\%)$ & 71.4 & 60 & 58.6 & 57.9 \\
\hline & Semi-confinement & 73.9 & 3.3 & Not used & Not used \\
\hline & $\mathrm{RR}(\%)$ & 82.14 & 85.71 & 77.41 & 84.21 \\
\hline \multirow[t]{6}{*}{ Low } & Manual weed control & Not used & 35.7 & 75 & 71.4 \\
\hline & $\mathrm{RR}(\%)$ & 53.6 & 40 & 38.7 & 73.7 \\
\hline & Herbicides & 100 & 87.5 & 50 & 55.6 \\
\hline & $\mathrm{RR}(\%)$ & 64.3 & 45.7 & 48.2 & 47.4 \\
\hline & Fire & 15.4 & 55.6 & 57.1 & 66.7 \\
\hline & $\mathrm{RR}(\%)$ & 46.4 & 51.4 & 48.2 & 47 \\
\hline
\end{tabular}

especially relevant for strategies that are particularly effective in precluding degradation such as the division-rotation of pastures and semi-confinement whose percentages are higher in the professional (100\% and $73.9 \%$, respectively) than in the traditional (53.8\% and 3.3\%, respectively). The low-impact strategies prevailed in the traditional system, where the percentages were higher for both manual weed control (professional not used versus traditional 35.7\%) and the use of fire (professional, 46.4\%; traditional, 51.4\%). Among low-impact strategies, an exception is the use of herbicides whose percentages are similar for both systems (professional 100\% versus traditional $87.5 \%$ ).

\section{Spatial diversity of systems}

As seen in Fig. 2, regardless of the scale of operations, the systems using high-impact strategies, i.e., professional and mixed, are found in regions with a consolidated infrastructure of roads, ports, dairy facilities, and slaughterhouses, either local or major (Fig. 2a). The mixed system extends to the less accessible BR230 (Transamazonica) and BR-163 regions, but still, it is predominantly concentrated in the Southeast and Northeast. Even though low-impact systems overlap the professional and mixed systems, they have a more widespread distribution, reaching the forest frontiers in the Southwest (Fig. 2b). As Fig. 3 shows, this spatial diversity is also seen when the behavior of different variables is analyzed in high- and low-impact systems. Accumulated deforestation, for instance, is higher under the professional and mixed systems, instead of in the traditional and subsistence systems whose spatial distribution over regions of forest frontiers implied lower accumulated deforestation (Fig. 3a). An inverse pattern is seen in Fig. $3 b$ when values of secondary vegetation per deforested land are compared among systems as there is less secondary vegetation per deforested land under high-impact systems than in systems with a prevalence of low-impact strategies.

Differences in the distribution of values of the price of bare land in 2015 are also observed. As Fig. 3c shows, the price of bare land was higher under the professional $(835.7+276.3)$ and mixed $(718.32+260.8)$ systems when compared with systems with lowimpact strategies, i.e., the traditional $(507.0 \pm 260.61)$ and subsistence $(590.02 \pm 267.4)$. Also, as local and major slaughtering facilities will be concentrated where infrastructure is better, the number of animals slaughtered was higher under high-impact systems (Fig. 3d). An inverse pattern though is observed when the embargo of lands for environmental offenses is analyzed: under systems with low-impact strategies, the amount of land under embargo in 2014 was higher in systems with low-impact strategies in comparison with high-impact systems (Fig. 3e).

Contrarily from what was reported in the field, the use of fire in 2014 was higher in the mixed $(2.6 \pm 41.4)$ and professional $(18.5 \pm 23.3)$ systems and lower in the traditional $(12.8 \pm 24.3)$ and subsistence $(19 \pm 27.1)$ (Fig. 3f). As the use of fire without licensing is an environmental offense, even when pasture management is concerned, we consider that informants might have

Fig. 2 High-impact (professional and mixed) and low-impact (traditional and subsistence) systems and the spatial convergence of infrastructure with high-impact systems (a) and forest stocks with low-impact systems (b and lands of high (c) and low (d) agriculture adequacy with high- and low-impact systems, respectively 


\section{Cattle Raising Systems}
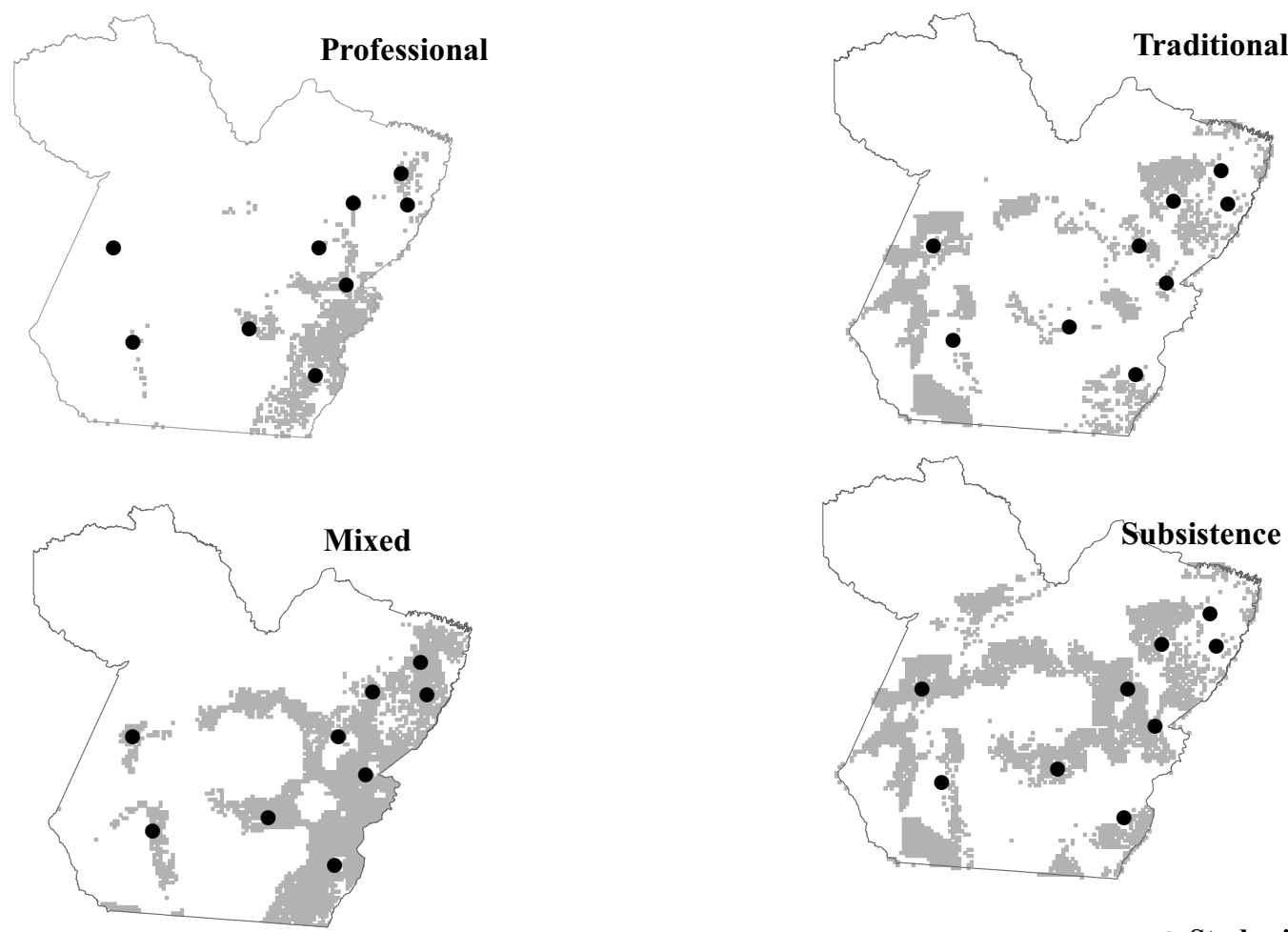

- Study sites
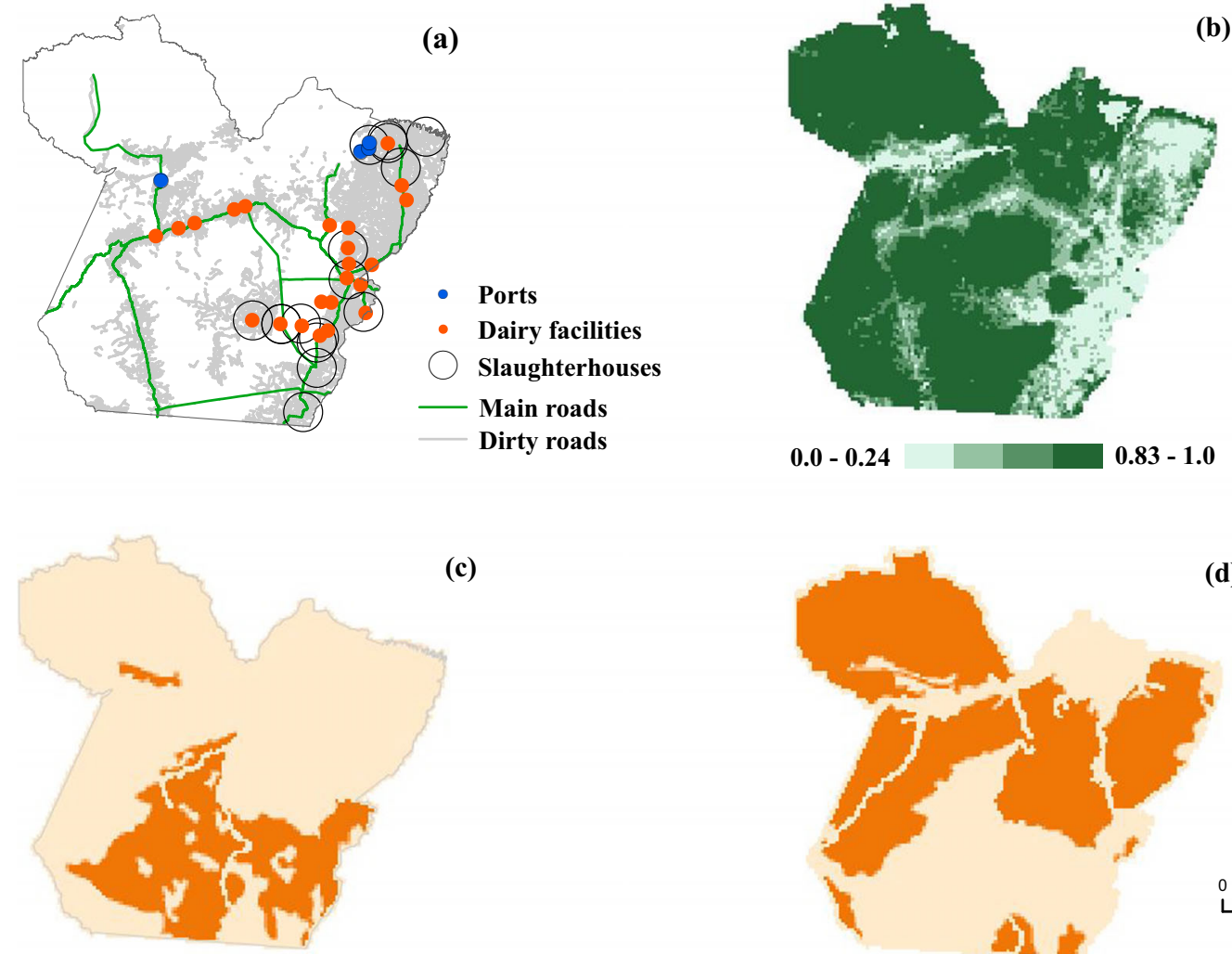

(c)

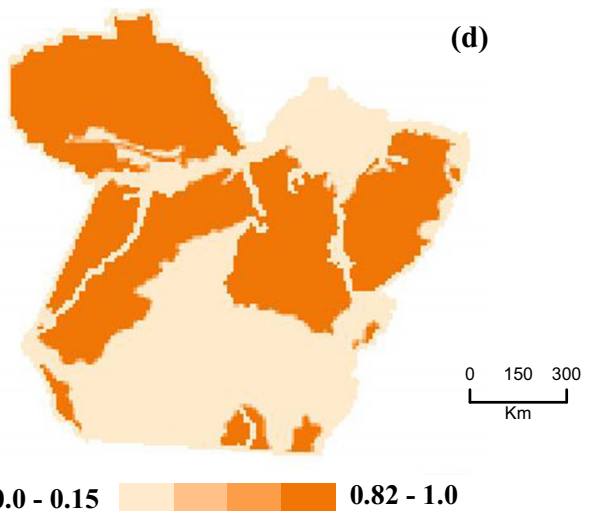


(a)

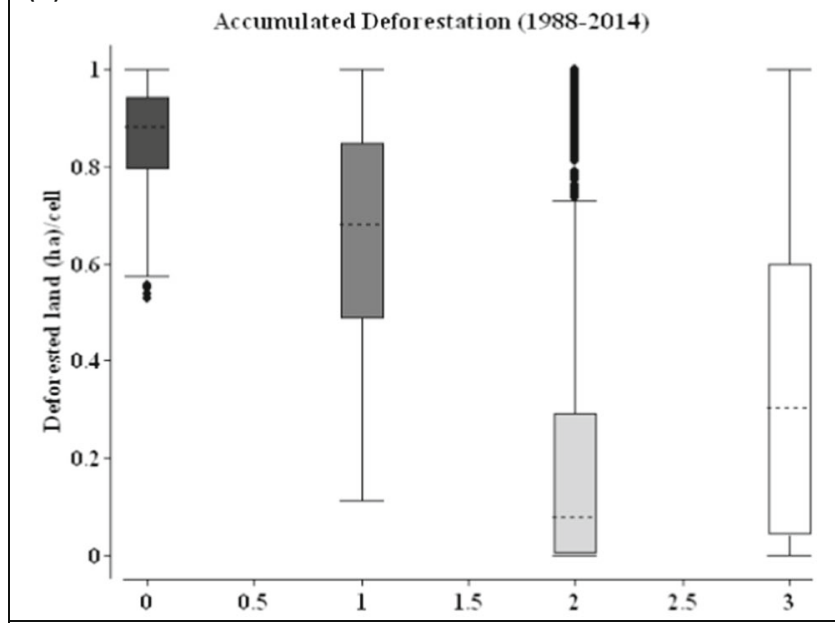

(c)

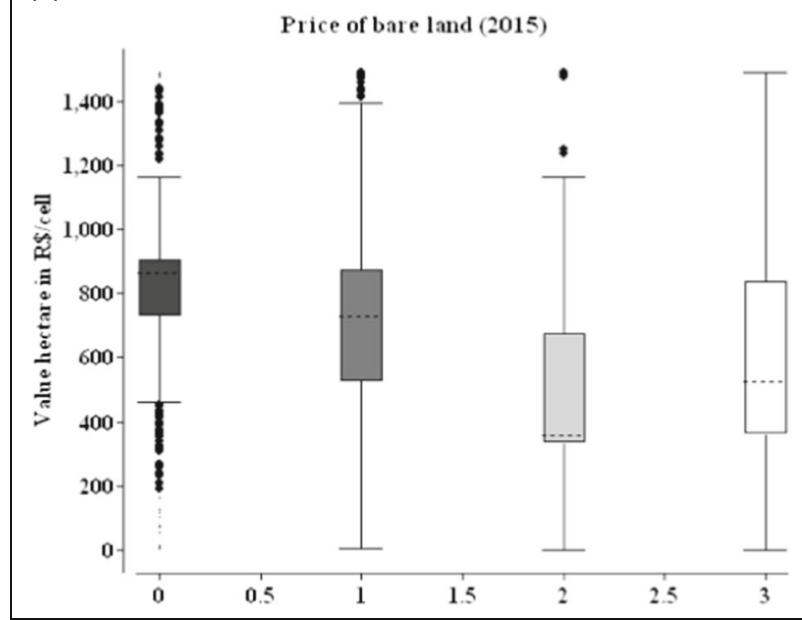

Fig. 3 The spatial diversity of cattle raising systems as reflected in the behavior of different variables. More accumulated deforestation (a) and less secondary vegetation per deforested land (b) under high-impact systems. Prices of bare land (c) and slaughtering (d) are also higher under high-impact systems, reflecting the effects of a concentration of (b)

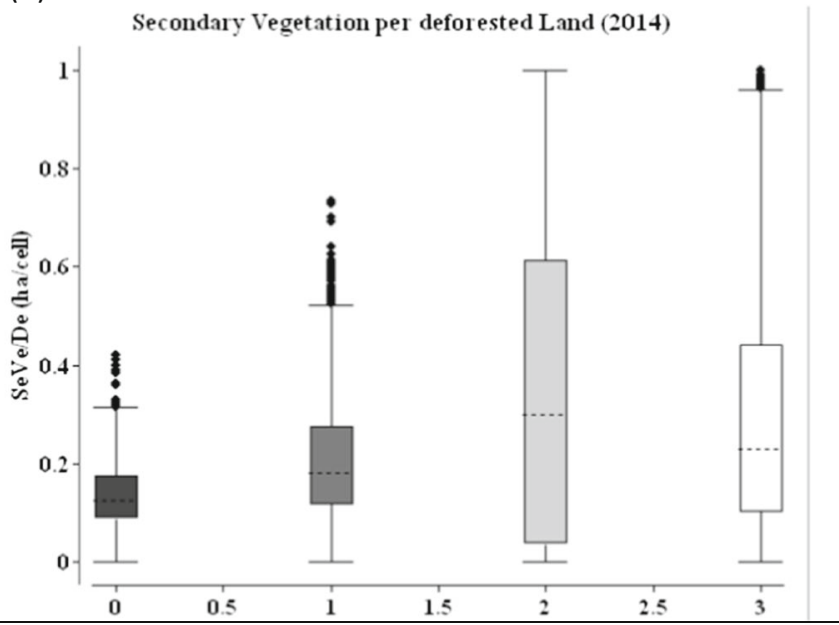

(d)

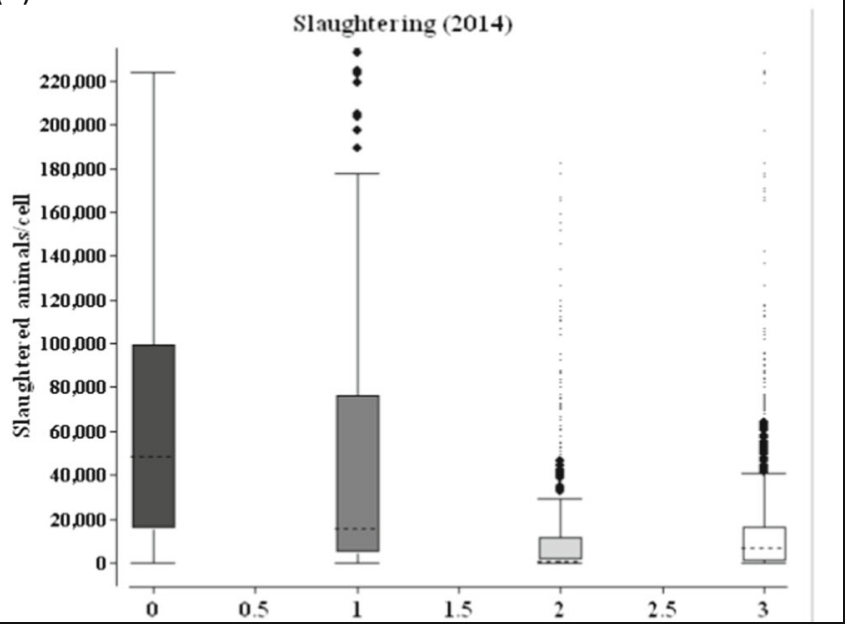

infrastructure. e More embargoed land under low-impact systems. f More foci of fire under high-impact systems although the use of fire was lower in comparison with low-impact systems according to interviews. Under the spatial distribution of high-impact systems, more properties used agrochemicals (g) and bulldozers (h)

system occupied 86.1 thousand $\mathrm{km}^{2}$ in 2014 which meant an expansion of $5.28 \%$ in comparison with that in 2004 . The same is observed for the mixed system that expanded $14.5 \%$. Low-impact systems, on the other hand, shrunk in between: the traditional system was reduced in $-36.79 \%$ and the subsistence in $-24.8 \%$. The observed expansion of systems with high-impact strategies concomitantly to the reduction in low-impact systems indicates that pressure against deforestation demotivated the expansion of cattle raising over newly deforested areas, eventually forcing the adoption of more intensive strategies to deal with pasture degradation.

To understand whether the spatial-temporal dynamics of high- and low-impact systems related to the dynamics of secondary vegetation, we analyzed the quantitative spatial distribution of the total area and the area under clusters of high 

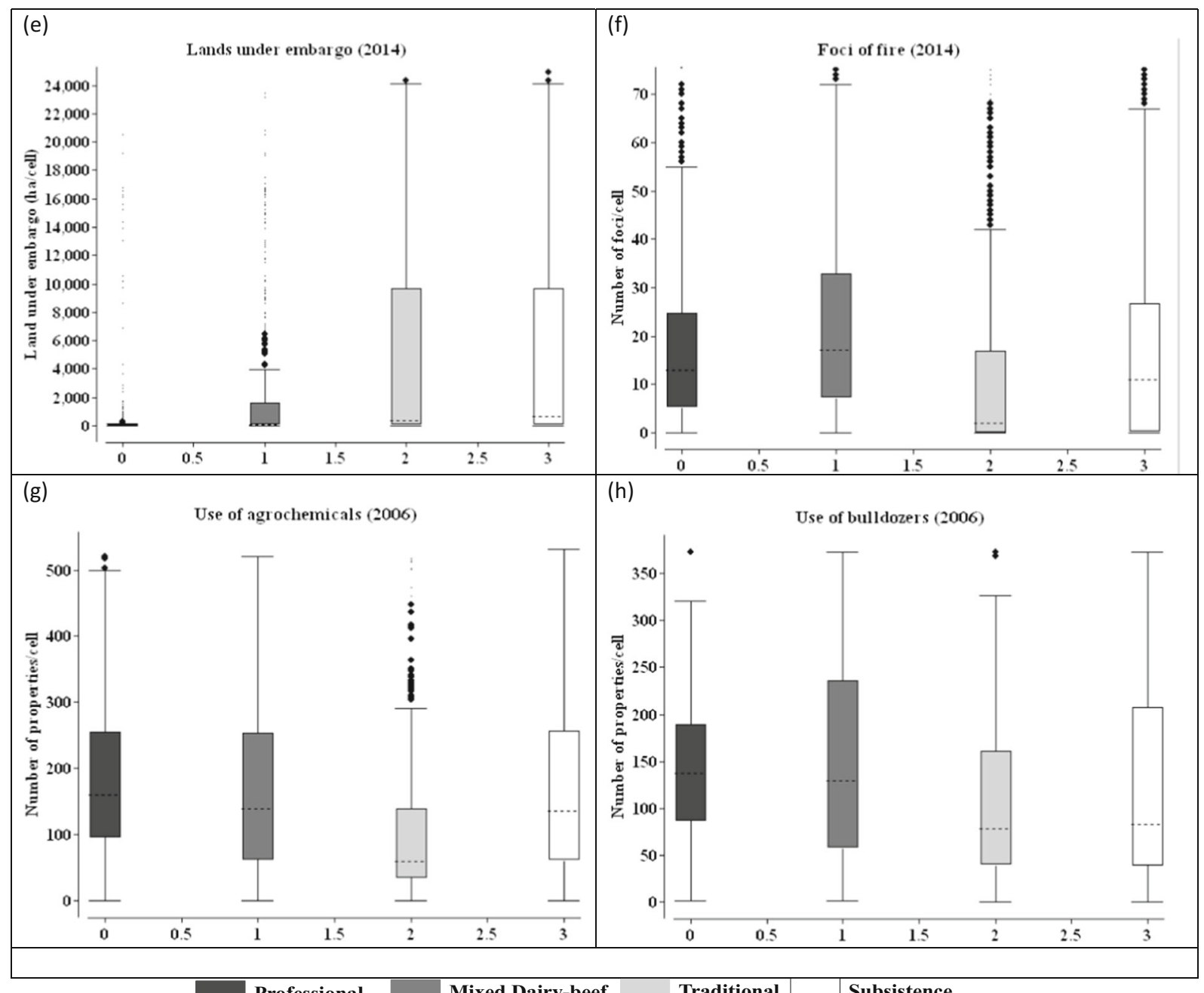

Professional

Mixed Dairy-beef

Traditional

Subsistence

Fig. 3 (continued)

(hotspots) and low (cold spots) values of secondary vegetation per deforested land (SeVe/De) among different systems. Figure 4 illustrates how the high and low values of secondary vegetation per deforested land are clustered in different systems.

As seen in Fig. 5a, when the total area of $\mathrm{SeVe} / \mathrm{De}$ is analyzed, these values increased by $+32 \%$ and $+10.8 \%$ in the mixed and professional systems, concomitantly decreasing by $-35.5 \%$ and $-10.6 \%$ in the traditional and subsistence systems. As these systems were substantially reduced over time, these differences were expected regardless of the management applied. However, when cold spots and hotspots are analyzed, we see that while cold spots of $\mathrm{SeVe} / \mathrm{De}$ expanded in high-impact systems, i.e., the mixed (+69.7) and professional $(+54.8)$, the systems better characterized by lowimpact strategies; i.e., the traditional $(-7.45 \%)$ and subsistence $(-78.4 \%)$ experienced a reduction in the area occupied by cold spots of $\mathrm{SeVe} / \mathrm{De}$. Changes in hotspots were
Table 2 Quantitative evolution of the area occupied by high- and low-impact cattle raising systems between 2004 and 2014

\begin{tabular}{lllllrr}
\hline Impact & System & $\begin{array}{c}\text { Area in } 2004 \\
\left(10,000 \mathrm{~km}^{2}\right)\end{array}$ & $\%^{(1)}$ & $\begin{array}{r}\text { Area in } 2014 \\
\left(10,000 \mathrm{~km}^{2}\right)\end{array}$ & $\%^{1}$ & $\%^{2}$ \\
\hline High & Professional & 81.8 & 6.56 & 86.1 & 6.90 & 5.28 \\
& Mixed dairy-beef & 232.8 & 18.66 & 266.8 & 21.38 & 14.57 \\
\multirow{2}{*}{ Low } & Traditional & 266.1 & 21.32 & 168.1 & 13.48 & -36.79 \\
& Subsistence & 388.0 & 31.10 & 291.6 & 23.37 & -24.84 \\
\hline
\end{tabular}

${ }^{1}$ Percentage of area occupied by the system relative to the total area of Pará

${ }^{2}$ Percentage of change in the area occupied by the system relative to the previous period 

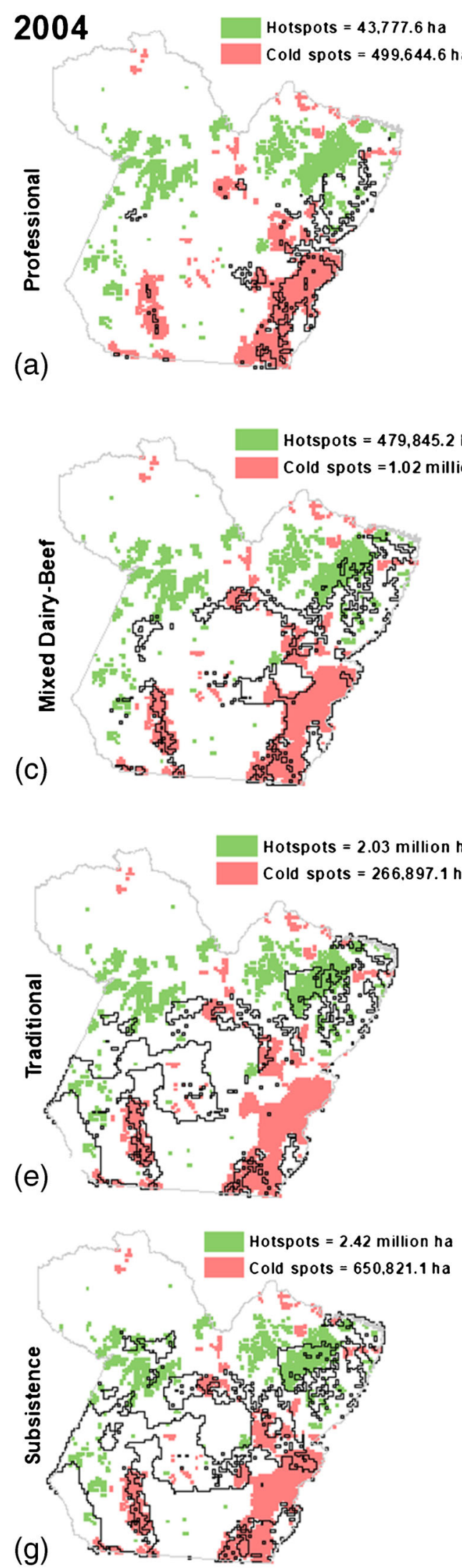

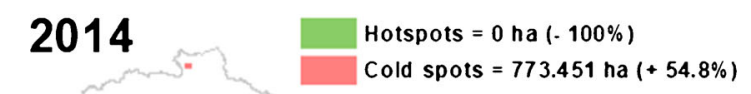

(b)

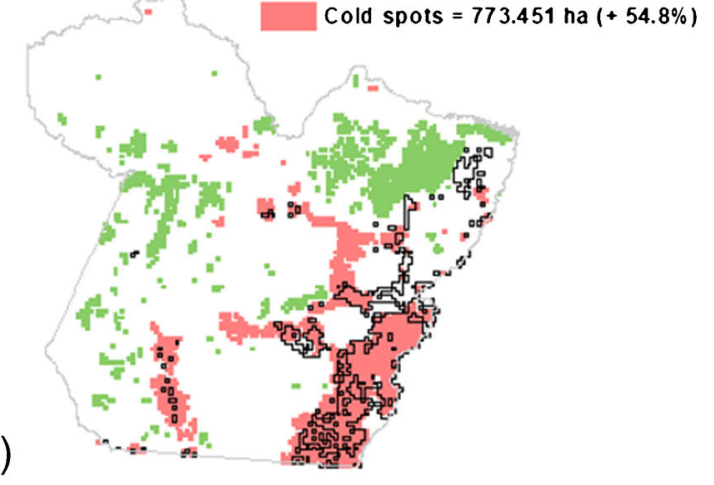

(d)
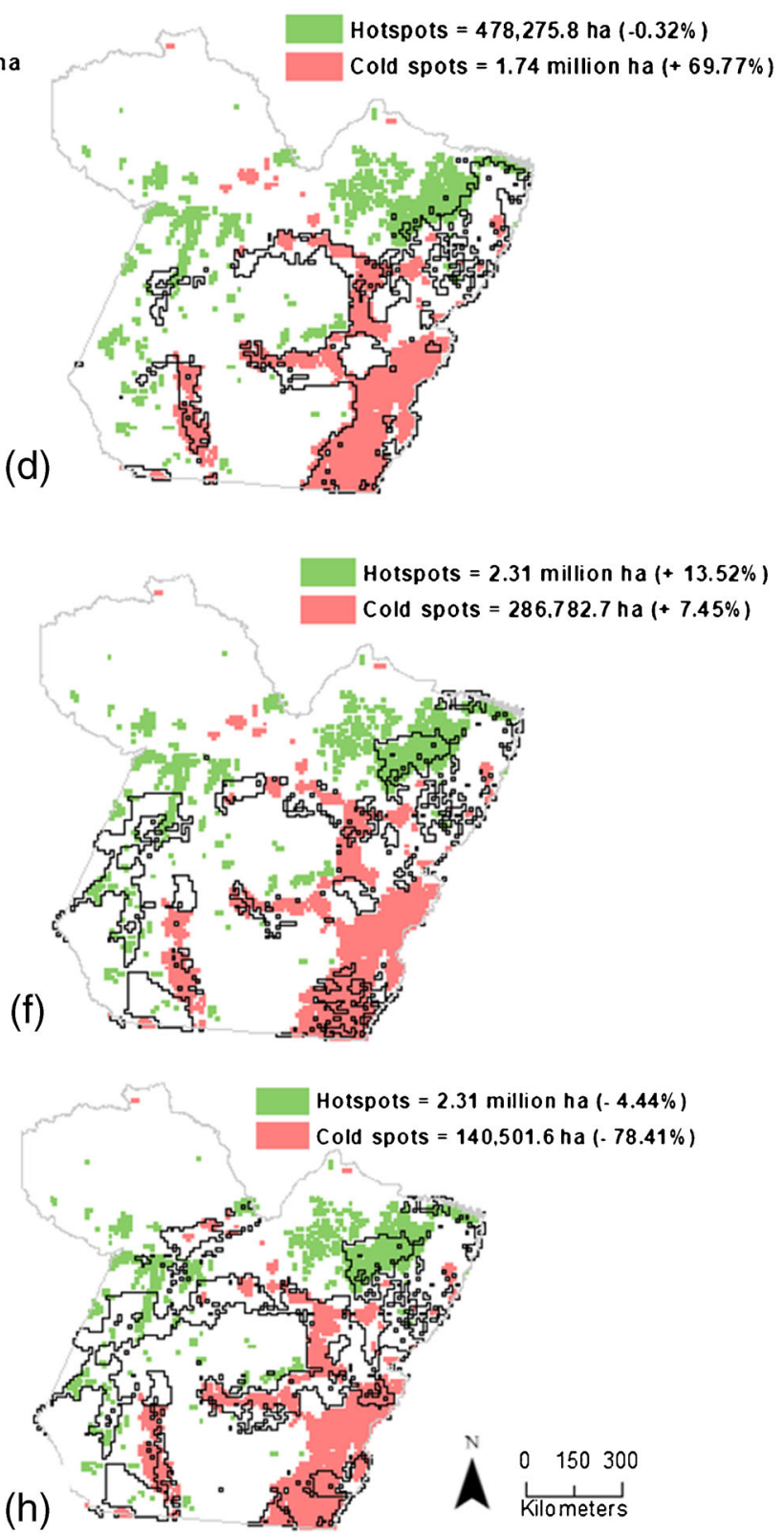

Fig. 4 a-h Cattle raising systems (black lines) superimposed over clusters of low (cold spots) and high values of secondary vegetation in 2004 (left) and 2014 (right). Values on the legends indicate the area occupied by clusters and the percentages of change between years 

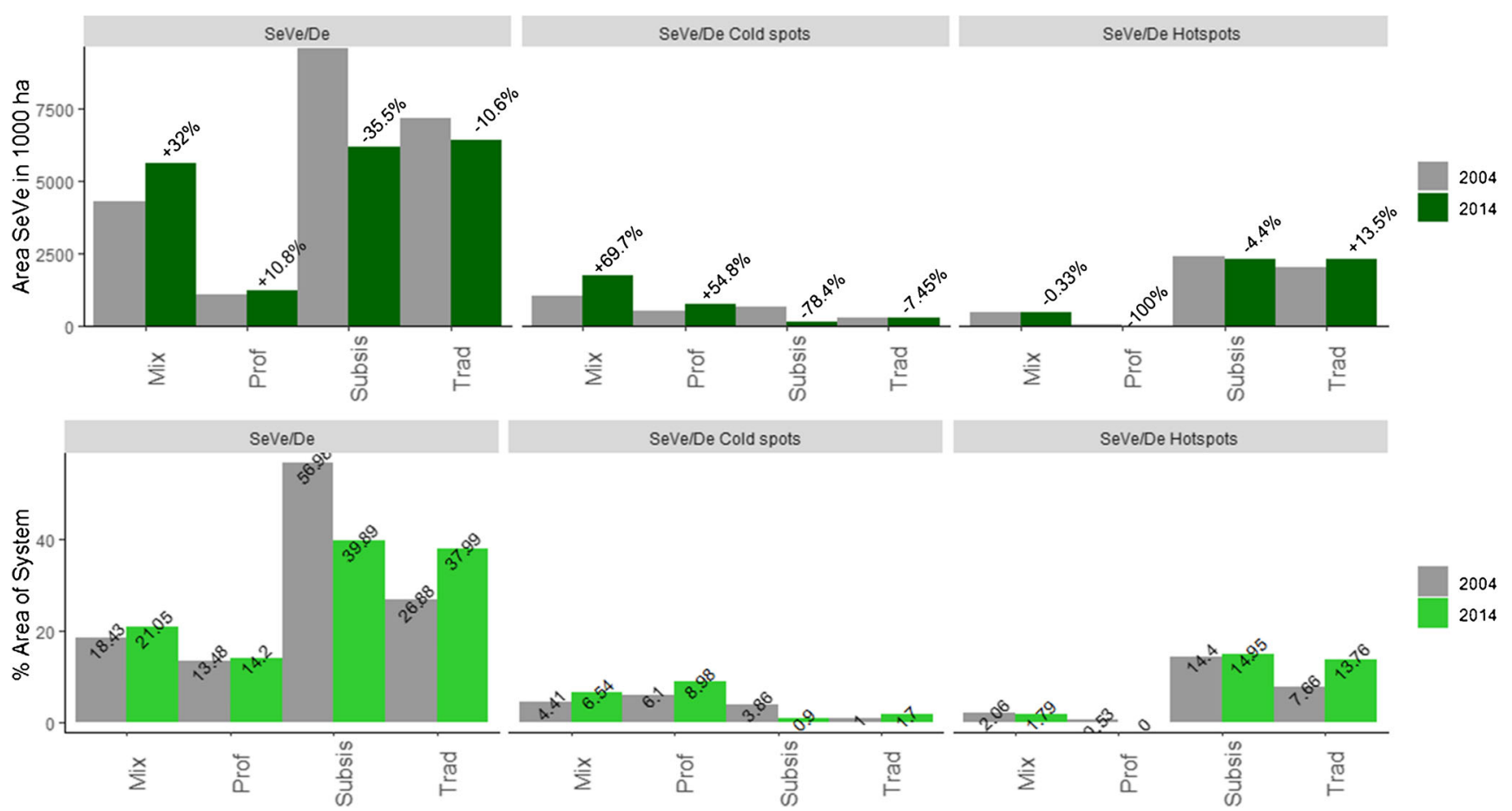

Fig. 5 Spatial-temporal dynamics of secondary vegetation per deforested area $(\mathrm{SeVe} / \mathrm{De})$ in different systems in 2004 and 2014. a Area of secondary vegetation and area of clusters of high (hotspots) and low (cold

prominent only in large-scale systems, where they decreased in the professional system $(-100 \%)$ and increased in the traditional system $(+13.5)$.

As shown in Fig. 5b, a similar pattern is observed when we analyzed the percentages of the total area and the area of clusters of high and low values of $\mathrm{SeVe} / \mathrm{De}$ relative to the area occupied by different systems. In high-impact systems, the percentages of cold spots were not only higher in both periods but also increased over time (professional from 6.1 to $8.98 \%$ and mixed from 4.41 to $6.54 \%)$. Under low-impact systems, the percentages of the area under cold spots of $\mathrm{SeVe} / \mathrm{De}$ decreased in the subsistence system (3.66 to $0.9 \%$ ) and slightly increased in the traditional (1 to $1.7 \%$ ). Following an opposite trend, the percentages of hotspots of SeVe/ De were lower and decreased over time in both high-impact systems, i.e., professional (2.53 to $0 \%)$ and mixed (2.06 to $1.79 \%)$, being higher in the traditional (7.66 to $13.76 \%$ ) and subsistence (14.4 to $14.95 \%$ ) where increase was very small though.

\section{Discussion}

Far from being steady and invariable, the most pervasive landuse in the Brazilian Amazon proves to be diverse, with smalland large-scale operations being developed through systems characterized by different strategies of pasture management, as well as by other attributes, that co-exist in time and space. Our spatial-temporal analyses put in evidence that this spots) values per deforested land. b Percentages of total area and area of clusters of secondary vegetation per deforested land relative to the area occupied by different systems

diversity implied different dynamics of secondary vegetation that, as a result of the use of high- or low-impact strategies, either precluded or favored regrowth in different systems. While unveiling how diverse cattle raising systems are spatially distributed, we have also found that the adoption of high-impact strategies to deal with pasture degradation is still restricted as seen by the spatial distribution of the professional and mixed systems. Under these high-impact systems, the historical expansion of infrastructure and proximity to the South of Brazil implied reduction in primary forests, configuring landscapes where secondary vegetation has also been reduced, a pattern already described in the Brazilian Amazon (Alves et al. 2003; Almeida et al. 2010). Yet, lowimpact systems prevail, reproducing the historical pattern of cattle raising that still favors the accumulation of secondary vegetation as it advances over forest frontiers. As suggested by the reduction in the spatial distribution of these systems though, the pressure against deforestation seems to have controlled the expansion of pastures over newly deforested lands, concomitantly motivating an intensification of pasture management. However, different regional conditions associated with the spatial distribution of high- and low-impact systems might as well be important to understand these dynamics.

\section{Systems and pasture management strategies}

Considering the effects of strategies used in pasture management, cattle raising operations in Pará are developed through 
high-impact, i.e., professional and mixed, and low-impact, i.e., traditional and subsistence, systems. Under high-impact systems, pasture management has been intensified through the adoption of strategies that increase grasses' competitiveness, therefore precluding the degradation of pastures (Uhl et al. 1988; Moran et al. 1994; Nepstad et al. 1996; Dias-Filho 2011, 2015). Either as a result of inadequate implementation or management, pasture degradation is estimated to affect $50 \%$ of pastures in the region (Dias-Filho, 2015). In such a context, it remains to be understood whether the management of pastures through high-impact strategies such as division and rotation, chemical fertilization, and semi-confinement could be sustainable from an economic perspective as costs are expected to be high. Semi-confinements present better prospects in this regard, with increased turnovers and the reduced pressure over pastures during dry periods being some of the advantages pointed out by cattle breeders. Also, areas cultivated with crops to feed animals can be turned into pastures, thus compensating investments in liming, chemical fertilization, and mechanization. However, as it will be discussed below, semi-confinements focus mostly on fattening, and questions arise concerning the out-farm impacts of expanding this strategy.

Under low -impact systems, i.e., traditional and subsistence, pastures are still predominantly managed using fire, herbicides, and manual weed control. Besides their little or no effect on precluding pasture degradation, these strategies can also have negative effects in terms of soil fertility and depletion of their physical properties, potentially increasing the severity of degradation (Uhl et al. 1988; Moran et al. 1994; Nepstad et al. 1996; Dias-Filho 2011). As these systems cover the majority of cattle operations in Pará, it is intriguing that, under such conditions of poor pasture management, clean pastures still expanded $16.5 \%$, herds doubled (from 10.2 to 20.2), and exports of beef and live cattle steadily increased (Pacheco and Poccard-Chapuis 2012; IBGE 2016; ComexStat/MDIC 2016). While pressure over the beef production chain played an important role in reducing the expansion of pastures over newly deforested lands, only gains in productivity could have sustained the observed increases in cattle production; however, as various authors have already emphasized, these changes are restricted and conditioned to specific contexts (Bowman et al. 2012; Pacheco and Poccard-Chapuis 2012; Vale et al. 2019).

\section{Spatial diversity of systems}

Developed as large-scale and low agriculture input systems, most forest clearing in the Brazilian Amazon is the outcome of cattle raising expansion (Walker et al. 2009; Bowman et al. 2012; Lapola et al. 2014; Almeida et al. 2016a, b). Since 2004, and particularly after 2009 , pressure over the beef production chain to halt deforestation is said to have motivated changes in operations of meatpackers and cattle breeders, as major slaughterhouses favored purchasing from properties without deforestation (Pacheco and Poccard-Chapuis 2012; Gibbs et al. 2016). Although little is known about how cattle raising operations changed to reduce deforestation, some authors argue that intensification of pastures and herd management increased productivity, thus reducing the expansion over primary forests (Pacheco and Poccard-Chapuis 2012; Arima et al. 2014). Others emphasize that there is little evidence connecting the reduction in deforestation rates after 2004 to other initiatives beyond law enforcement and that removal of land from production, effective monitoring mechanisms, and improved law enforcement would be the catalytic forces of intensification (Merry and Soares-Filho 2017).

As seen in Pará, a hotspot of deforestation, the adoption of high-impact strategies of pasture management was restricted to sites with a consolidated infrastructure of roads, ports, dairy facilities, slaughterhouses, and higher accumulated deforestation. Where such conditions did not apply, cattle raising operations are developed through low-impact systems, i.e., traditional and subsistence which, despite overlapping high-impact systems, had a widespread distribution extending to forest frontiers. Also, while high-impact systems expanded over time, low-impact systems experienced considerable reductions. These distinct dynamics could be the result of pressure against deforestation that motivated intensification, either through improved pasture management or the expansion of semi-confinements, at the same time controlling the expansion of pastures over newly deforested lands (Arima et al. 2014; Lapola et al. 2014; Gibbs et al. 2016). However, several other economic, environmental, legal, and social factors may influence where, to what extent, and at what speed intensification takes place, and despite the complexity of such a task, assessing the key factors motivating the adoption of more intensive strategies is crucial, especially considering that cattle raising intensification programs (CRIPs) are currently focused as means to conserve forests and reduce emissions (Cohn et al. 2011; Latawiec et al. 2014).

Between 1996 and 2006, pastures expanded only 3.4 million ha (50.4 to 53.4 million ha) what in a scenario of no increased productivity, the recorded expansion of herds in this period would require an additional 20 million ha of pasture (Pacheco and Poccard-Chapuis 2012). Based on a set of parameters of productivity, these authors state that cattle herd management in medium- and large-scale properties was improved. In Pará, the factors motivating intensification were the consolidated infrastructure, particularly regarding major slaughterhouses, and the higher land prices which also connect with the consolidated infrastructure and high agriculture adequacy. As shown by Gibbs et al. (2016), in a 10-km range from slaughtering facilities, there was a significant reduction in deforestation rates following the G4 zero-deforestation agreement signed by major industrial slaughterhouses in 
2009 which, in parallel with public prosecuting actions, has put industrial slaughterhouses under scrutiny, potentially changing cattle raising operations. Indeed, proximity to federally inspected slaughterhouses (SIF facilities) was related to pasture intensification in Mato Grosso (Garrett et al. 2018). Southeastern Pará where the professional system is particularly concentrated also presents relatively higher loss what may increase the opportunity costs of complying with legal measures as described by Borner et al. (2014). These findings help explain the spatial distribution of high-impact systems found in Pará. Still important is the expansion of confinements in increasing cattle productivity: between 2009 and 2012, concomitantly with increased pressure against deforestation, confinements expanded in the biome, particularly in Rondonia and Pará, where new 42 confinements emerged in the period (Vale et al. 2019).

Still, concerning the intensification of cattle raising, the fact that high-impact systems are concentrated in regions with high accumulated deforestation also deserves attention. As hypothesized by White et al. (2001), this could be a prerequisite for intensification as in the context of nascent markets and low land values, continued deforestation, and extensive cattle production would be more rational choices but as markets develop and land prices rise, intensification would be a better option instead of expanding over more valuable lands. Yet, a better understanding of the background and trajectories of actors in cattle raising systems is still necessary to illuminate the driving forces towards intensification and to provide a better understanding of whether such initiatives will indeed produce forest conservation outcomes.

\section{Spatial-temporal dynamics of systems and secondary vegetation}

As approximately $60 \%$ of all deforested lands in the Brazilian Amazon are covered by pastures, it is expected that the spatial diversity of cattle raising will continue to play a major role in the dynamics of Pará landscapes, not only regarding deforestation. Under high-impact systems, both in terms of the total area of this cover or the area under hotspots, the strategies used to manage pastures had a negative effect over secondary. On the other hand, intensification of pasture management is still restricted and, as our spatial-temporal analyses show, under low-impact systems, pasture management has been of little or no effect to preclude degradation. Therefore, given the negative effects of high-impact systems over regrowth and their concentration in regions where accumulated deforestation is higher, the intensification of cattle production has the potential to configure landscapes with reduced forests, either primary or secondary. On the other hand, in forest frontiers, low-impact systems reproduce the historical pattern of expansion of pastures over primary forests, early abandonment, and accumulation of secondary vegetation.

\section{Conclusions}

Although cattle raising is still mostly developed through systems where low-impact strategies of pasture management prevail, intensification is already a consistent trend that is expected to gain force vis-à-vis measures against deforestation, availability of specific lines of credit (e.g., the Low Carbon Agriculture - ABC Program), and financial support from conservation programs are put in place. Until the beginning of the 2000 s, the major challenge regarding cattle raising was to control its expansion to reduce deforestation. Intensification of pasture management through the adoption of high-impact strategies and their negative effects over regrowth call attention to new challenges that intensification may present such as monitoring the overall environmental impacts besides deforestation.

Intensification in Pará is emerging under a set of conditions, i.e., better infrastructure and access to market and higher accumulated deforestation; therefore, understanding these underlying conditions and its potential links to the regional landscape dynamics in the biome is particularly relevant to deal with the potential socio-environmental impacts of cattle raising expansion. Considering that the adoption of more intensive strategies may not be capable to spare land but, on the contrary, imply more (legal or illegal) conversion of primary forests into pastures, incentives to intensification have the potential to configure landscapes with reduced forested areas, either primary or secondary.

Funding information Open access funding provided by Stockholm University.

Open Access This article is licensed under a Creative Commons Attribution 4.0 International License, which permits use, sharing, adaptation, distribution and reproduction in any medium or format, as long as you give appropriate credit to the original author(s) and the source, provide a link to the Creative Commons licence, and indicate if changes were made. The images or other third party material in this article are included in the article's Creative Commons licence, unless indicated otherwise in a credit line to the material. If material is not included in the article's Creative Commons licence and your intended use is not permitted by statutory regulation or exceeds the permitted use, you will need to obtain permission directly from the copyright holder. To view a copy of this licence, visit http://creativecommons.org/licenses/by/4.0/.

\section{References}

Aguiar APD, Vieira ICG, Assis TO, Dalla-Nora EL, Toledo PM, Oliveira Santos-Junior RA, Nobre CA (2016) Land use change emission scenarios: anticipating a forest transition process in the Brazilian Amazon. Glob Chang Biol 22:1821-1840. https://doi.org/10.1111/ gcb. 13134

Aguiar APD, Ometto JP, Nobre C, Lapola DM, Almeida C, Vieira IC, Soares JV, Alvala R, Saatchi S, Valeriano D, Castilla-Rubio JC 
(2012) Modeling the spatial and temporal heterogeneity of deforestation-driven carbon emissions: the INPE-EM framework applied to the Brazilian Amazon. Glob Chang Biol 18:3346-3366. https://doi.org/10.1111/j.1365-2486.2012.02782.x

Alix-Garcia J, Rausch LL, L'Roe J, Gibbs HK, Munger J (2018) Avoided deforestation linked to environmental registration of properties in the Brazilian Amazon. Conserv Lett 11(3):e12414. https://doi.org/ 10.1111/conl.12414

Almeida CA, Valeriano DM, Escada MIS, Rennó CD (2010) Estimativa de área de vegetação secundária na Amazônia Legal Brasileira. Acta Amazon 40:289-302. https://doi.org/10.1590/s004459672010000200007

Almeida C, Mourão M, Dessay N, Lacques AE, Monteiro A, Durieux L, Venturieri A, Seyler F (2016a) Typologies and spatialization of agricultural production systems in Rondônia, Brazil: linking land use, socioeconomics and territorial configuration. Land 5(2):18. https:// doi.org/10.3390/land5020018

Almeida CA, Coutinho AC, Esquerdo JCDM, Adami M, Venturieri A, Diniz CG, Dessay N, Durieux L, Gomes AR (2016b) High spatial resolution land use and land cover mapping of the Brazilian Legal Amazon in 2008 using Landsat-5/TM and MODIS data. Acta Amazon 46:291-302. https://doi.org/10.1590/18094392201505504

Almeida CA, Dessay N, Laques AE, Carvalho R (2019) Sistemas produtivos agropastoris (SPA) em Rondônia: Uma análise de paisagens aplicada ao monitoramento de mudanças de uso e cobertura da terra. Anais do XIX Simposio Brasileiro de Sensoriamento Remoto, Santos. Available from: http://urlib.net/ rep/8JMKD3MGP6W34M/3U6G342

Alves DS, Escada MIS, Pereira JLG, Linhares CA (2003) Land-use intensification and abandonment in Rondônia, Brazilian Amazônia. Int J Remote Sens 24(4):899-903. https://doi.org/10.1080/ 0143116021000015807

Arima EY, Barreto P, Araújo E, Soares-Filho B (2014) Public policies can reduce tropical deforestation: lessons and challenges from Brazil. Land Use Policy 41:465-473. https://doi.org/10.1016/j.landusepol. 2014.06.026

Arima EY, Barreto P, Brito M (2005) Pecuária na Amazônia: tendências e implicações para a conservação ambiental. Instituto do Homem e Meio Ambiente da Amazônia-IMAZON, Belém

Bernard HR (2006) Research methods in anthropology: qualitative and quantitative approaches. Rowman \& Littlefield, Oxford

Baruch Y (1999) Response rate in academic studies - a comparative analysis. Hum Relat 52:421-438. https://doi.org/10.1177/ 001872679905200401

Benayas JMR, Newton AC, Diaz A, Bullock JM (2009) Enhancement of biodiversity and ecosystem services by ecological restoration: a meta-analysis. Science 325:1121-1124. https://doi.org/10.1126/ science. 1172460

Borner J, Wunder S, Kannonnikoff SW, Hyman G, Nascimento N (2014) Forest law enforcement in the Brazilian Amazon: costs and income effects. Glob Environ Chang 29:294-305. https://doi.org/10.1016/j. gloenvcha.2014.04.021

Bowman MS, Soares-Filho BS, Merry FD, Nepstad DC, Rodrigues H, Almeida O (2012) Persistence of cattle ranching in the Brazilian Amazon: a spatial analysis of the rationale for beef production. Land Use Policy 29:558-568. https://doi.org/10.1016/j.landusepol. 2011.09.009

Carvalho R, Adami M, Amaral S, Bezerra FG, Aguiar APD (2019) Changes in secondary vegetation dynamics in a context of decreasing deforestation rates in Pará, Brazilian Amazon. Appl Geogr 106: 40-49. https://doi.org/10.1016/j.apgeog.2019.03.001

Cezar IM, Queiroz HP, Thiago LRLS, Cassales FLG, Costa FP (2005) Sistemas de produção de gado de corte no Brasil: uma descrição com ênfase no regime alimentar e no abate. Embrapa Gado de Corte, Campo Grande
Comex-Stat/Mdic (2016) Plataforma de consulta a dados de comércio exterior. http://comexstat.mdic.gov.br/pt/home. Accessed 30 March 2019

Cohn A, Bowman M, Zilberman D, O’Neill K (2011) The viability of cattle ranching intensification in Brazil as a strategy to spare land and mitigate greenhouse gas emissions. CCAFS Working Paper no. 11. CGIAR Research Program on Climate Change, Agriculture and Food Security (CCAFS). Copenhagen, Denmark

Costa FDA (2004) Path dependency e a transformação agrária do bioma amazônico: o sentido econômico das capoeiras para o desenvolvimento sustentável. Novos Cadernos NAEA 7:111-158. https://doi.org/10.5801/ncn.v7i2.44

Costa FDA (2009) Dinâmica agrária e balanço de carbono na Amazônia. Revista Economia 10:117-151. https://anpec.org.br/revista/vol10/ vol10n1p117_151.pdf

Dias-Filho MB (2015) Estratégias de recuperação de pastagens degradadas na Amazônia brasileira. Embrapa Amazônia Oriental, Belém

Dias-Filho MB (2011) Degradação de pastagens: processos, causas e estratégias de recuperação. MBDF, Belém

Escada MIS, Vieira ICG, Kampel SA, Araújo R, Veiga JB, Aguiar APD, Veiga I, Oliveira M, Gavina JLP, Carneiro-Filho A, Fearnside PM, Venturieri A, Carriello F, Thales M, Carneiro TSG, Monteiro AMV, Câmara G (2005) Processos de ocupação nas novas fronteiras da Amazônia: o interflúvio do Xingu/Iriri. Estudos Avançados 19:923. https://doi.org/10.1590/s0103-40142005000200002

Garrett RD, Koh I, Lambin EF, de Waroux YLP, Kastens JH, Brown JC (2018) Intensification in agriculture-forest frontiers: land use responses to development and conservation policies in Brazil. Glob Environ Chang 53:233-243. https://doi.org/10.1016/j.gloenvcha. 2018.09.011

Gibbs HK, Munger J, L'Roe J, Barreto P, Pereira R, Christie M, Walker NF (2016) Did ranchers and slaughterhouses respond to zerodeforestation agreements in the Brazilian Amazon? Conserv Lett 9:32-42. https://doi.org/10.1111/conl.12175

Instituto Brasileiro de Geografia e Estatística - (IBGE) (2016) Pesquisa Pecuária Municipal. Retrieved in 1 September 2018, from https:// sidra.ibge.gov.br/pesquisa/ppm/quadros/brasil/2016

Kaimovitz D, Angelsen A (2008) Will livestock intensification help save latin america's tropical forests? J Sustain For 27:6-24. https://doi. org $/ 10.1080 / 10549810802225168$

Kelley K, Clark B, Brown V, Sitzia J (2003) Good practice in the conduct and reporting of survey research. Int J Qual Health Care 15:261266. https://doi.org/10.1093/intqhe/mzg031

Lambin EF, Gibbs HK, Heilmayr R, Carlson KM, Fleck LC, Garrett RD, Waroux YP, McDermott CL, McLaughlin D, Newton P, Nolte C, Pacheco P, Rausch LL, Streck C, Thorlakson T, Walker NFC (2018) The role of supply-chain initiatives in reducing deforestation. Nat Clim Chang 8(2):109. https://doi.org/10.1038/s41558-017-0061-1

Lapola DM, Martinelli LA, Peres CA, Ometto JP, Ferreira ME, Nobre CA, Aguiar APD, Bustamante MMC, Cardoso MF, Costa MH, Joly CA, Leite CC, Moutinho P, Sampaio G, Strassburg BBN, Vieira ICG (2014) Pervasive transition of the Brazilian land-use system. Nat Clim Chang 4:27-35. https://doi.org/10.1038/NCLIMATE2056

Latawiec AE, Strassburg BBN, Valentim JF, Ramos F, Alves-Pinto HN (2014) Intensification of cattle ranching production systems: socioeconomic and environmental synergies and risks in Brazil. Animal 8:1255-1263. https://doi.org/10.1017/s1751731114001566

Merry F, Soares-Filho B (2017) Will intensification of beef production deliver conservation outcomes in the Brazilian Amazon? Elementa: Science of the Anthropocene 5:2-12. https://doi.org/10.1525/ elementa.224

Mesquita RC, Massoca PES, Jakovac CC, Bentos TV, Williamson GB (2015) Amazon rain forest succession: stochasticity or land-use legacy? Bioscience 65:849-861. https://doi.org/10.1093/biosci/biv108 
Mesquita RC, Ickes K, Ganade G, Williamson GB (2001) Alternative successional pathways in the Amazon Basin. J Ecol 89:528-537. https://doi.org/10.1046/j.1365-2745.2001.00583.x

Moran EF, Brondizio E, Mausel P (1994) Secondary succession. Research \& Exploration 10:458-476

Neeff T, Alencastro-GraÇa PM, Dutra LV, Freitas C (2005) Carbon budget estimation in Central Amazonia: successional forest modeling from remote sensing data. Remote Sens Environ 94:508-522. https://doi.org/10.1016/j.rse.2004.12.002

Nepstad DC, Uhl C, Pereira CA, Silva JMCD (1996) A comparative study of tree establishment in abandoned pasture and mature forest of eastern Amazonia. Oikos 25-39. https://doi.org/10.2307/3545745

Orihuela-Belmonte DE, De Jong BHJ, Mendonza-Vega J, Vand der Wal J, Paz-Pellat F, Soto-Pinto L, Flamenco-Sandoval A (2013) Carbon stocks and accumulation rates in tropical secondary forests at the scale of community, landscape and forest type. Agric Ecosyst Environ 171:72-84. https://doi.org/10.1016/j.agee.2013.03.012

Pacheco P, Poccard-Chapuis R (2012) The complex evolution of cattle ranching development amid market integration and policy shifts in the Brazilian Amazon. Ann Assoc Am Geogr 102:1366-1390. https://doi.org/10.1080/00045608.2012.678040

Pereira CA, Vieira IC (2001) A importância das florestas secundárias e os impactos de sua substituição por plantios mecanizados de grãos na Amazônia. Interciência 26:337-344

Prodes (2019) Monitoramento da floresta Amazônica Brasileira por satélite. Instituto Nacional de Pesquisas Espaciais Projeto Prodes. http://www.obt.inpe.br/prodes/index. Accessed 1 June 2019

Strassburg BB, Latawiec AE, Barioni LG, Nobre CA, Silva, VPD, Valentim, JF, Assad, ED (2014) When enough should be enough: improving the use of current agricultural lands could meet production demands and spare natural habitats in Brazil. Glob Environ Chang 28:84-97. https://doi.org/10.1016/j.gloenvcha. 2014.06.001

Terraclass (2014) Levantamento de informações de uso e cobertura da terra na Amazônia. https:// ainfo.cnptia.embrapa.br/digital/ bitstream/item/152807/1/ TerraClass.pdf. Accessed 24 August 2018

Uhl C, Buschbacker R, Serrão EAS (1988) Abandoned pastures in eastern Amazonia. I patterns of plant succession. J Ecol 76:663-681. https://doi.org/10.2307/2260566

Vale P, Gibbs H, Vale R, Christie M, Florence E, Munger J, Sabaini D (2019) The expansion of intensive beef farming to the Brazilian Amazon. Glob Environ Chang 57:101922. https://doi.org/10.1016/ j.gloenvcha.2019.05.006

Walker R, Browder J, Arima E, Simmons C, Pereira R, Caldas M, Shirota R, Zen S (2009) Ranching and the new global range: Amazônia in the 21st century. Geoforum 40:732-745. https://doi.org/10.1016/j. geoforum.2008.10.009

Walker R, Moran E, Aanselin L (2000) Deforestation and cattle ranching in the Brazilian Amazon: external capital and household processes. World Dev 28:683-699. https://doi.org/10.1016/s0305-750x(99) 00149-7

White D, Holmann F, Fujisaka S, Reategui K, and Lascano C (2001) Will intensifying pasture management in Latin America protect forests or is it the other way round? In Agricultural Technologies and tropical deforestation, ed. A. Angelsen, Kaimowitz, D. London: CABI publishing. https://doi.org/10.1079/9780851994512.0091

Publisher's note Springer Nature remains neutral with regard to jurisdictional claims in published maps and institutional affiliations. 